\title{
Ralstonia taiwanensis sp. nov., isolated from root nodules of Mimosa species and sputum of a cystic fibrosis patient
}

\author{
1 Tajen Institute of \\ Technology, No. 20, \\ Wei-Shin Road, Shin-Erh \\ Village, Yen-Pu, Ping-Tung \\ 90703, Taiwan \\ 2 Laboratorium voor \\ Microbiologie, Universiteit \\ Gent, Gent, Belgium \\ 3 Environmental \\ Technology, Vlaamse \\ Instelling voor \\ Technologisch Onderzoek, \\ Belgium \\ 4 Laboratory for \\ Microbiology, Radioactive \\ Waste and Clean-up \\ Division, Center of Studies \\ for Nuclear Energy, Mol, \\ Belgium
}

\author{
Wen-Ming Chen, ${ }^{1}$ Severine Laevens, ${ }^{2}$ Tsong-Ming Lee, ${ }^{1}$ Tom Coenye, ${ }^{2}$ \\ Paul De Vos, ${ }^{2}$ Max Mergeay ${ }^{3,4}$ and Peter Vandamme ${ }^{2}$
}

Author for correspondence: Wen-Ming Chen. Tel: +886873306 04. Fax: +88687338600. e-mail:p62365@ms28.hinet.net

\begin{abstract}
A polyphasic taxonomic study, including 165 rDNA sequence analysis, DNA-DNA hybridizations, DNA base ratio determinations, amplified 16S rDNA restriction analysis, whole-cell protein analyses and extensive biochemical characterization, was conducted to clarify the relationships of eight isolates from root nodules of Mimosa species and one isolate from sputum of a cystic fibrosis patient. All nine isolates were classified as a novel Ralstonia species, for which the name Ralstonia taiwanensis sp. nov. is proposed. The type strain is LMG $19424^{\top}$ (= CCUG $44338^{\top}$ ). $R$. taiwanensis effectively nodulated the Mimosa species and is the first $\beta$-proteobacterium that is known to be capable of root nodule formation and nitrogen fixation.
\end{abstract}

Keywords: Ralstonia taiwanensis sp. nov., root nodules, Mimosa, taxonomy

\section{INTRODUCTION}

The genus Ralstonia was established in 1995 by Yabuuchi and others to accommodate species previously known as Alcaligenes eutrophus, Pseudomonas solanacearum and Pseudomonas pickettii (Yabuuchi et al., 1995). Since then, several additional species isolated from environmental or human clinical sources, or both, have been described: Ralstonia gilardii (Coenye et al., 1999); Ralstonia paucula (Vandamme et al., 1999); Ralstonia basilensis (Steinle et al., 1998); and Ralstonia mannitolytica (De Baere et al., 2001). These Ralstonia species occupy very diverse ecological niches. Ralstonia eutropha and $R$. basilensis are environmental micro-organisms, the former being isolated from sludge, soil and waste-water (Steinle et al., 1998). Ralstonia solanacearum is one of the most important bacterial phytopathogenic species, causing bacterial wilt on a wide range of crops (Palleroni \& Doudoroff, 1971). Ralstonia pickettii, R. mannitolytica, $R$. paucula and $R$. gilardii strains have been isolated from various clinical sources and environmental samples (Riley \& Weaver, 1975; Coenye et al., 1999; De Baere et al., 2001; Vandamme et al., 1999).

\footnotetext{
Abbreviation: ARDRA, amplified rDNA restriction analysis.

The GenBank/EMBL/DDBJ accession numbers for the $16 \mathrm{~S}$ rDNA sequences of strains LMG $19424^{\top}$ and LMG 19425 are AF300324 and AF300325, respectively.
}

The genus Ralstonia is thus a most unusual genus, unifying species that are opportunistic human pathogens able to survive in oligotrophic environments with economically important plant pathogens and organisms that are of considerable biotechnological interest because of their potential for biodegradation of recalcitrant components and xenobiotics.

In the present study, polyphasic taxonomic analysis was used to elucidate the taxonomic relationships of eight isolates from root nodules of Mimosa species and one isolate from the sputum of a cystic fibrosis patient. These isolates were shown to represent a novel Ralstonia species, for which the name Ralstonia taiwanensis sp. nov. is proposed.

\section{METHODS}

Bacterial strains. R. taiwanensis strains and the Ralstonia reference strains used are listed in Table 1. The root nodule strains of Mimosa pudica and Mimosa diplotricha were collected from three fields at Ping-Tung Country in the southern part of Taiwan. Root nodules were immersed in $95 \%$ ethanol for $10 \mathrm{~s}$, sterilized in $0.1 \%(\mathrm{w} / \mathrm{v})$ mercuric chloride for $10 \mathrm{~min}$ and then washed six times with sterile distilled water. With sterile glass rods, individual nodules were crushed and streaked onto yeast extract-mannitol agar (Vincent, 1970) and incubated at $28^{\circ} \mathrm{C}$. Single colonies were selected and re-streaked for purity.

Analysis of protein electrophoretic patterns. Strains were incubated for $48 \mathrm{~h}$. Preparation of cellular protein extracts, 
Table 1. List of strains studied

Abbreviations: API, Appareils et Procédés d'Identification, Marcy-l'Etoile, France; ATCC, American Type Culture Collection, Manassas, VA, USA; CCUG, Culture Collection University of Göteborg, Sweden; CDC, Centers for Disease Control and Prevention, Atlanta, GA, USA; DSMZ, Deutsche Sammlung von Mikroorganismen und Zellkulturen, Braunschweig, Germany; LMG, BCCM/LMG Bacteria Collection, Laboratorium voor Microbiologie Gent, Gent, Belgium; NCIMB, National Collection of Industrial and Marine Bacteria, National Collections of Industrial, Food and Marine Bacteria, Aberdeen, UK; NCPPB, National Collection of Plant-pathogenic Bacteria, Harpenden Laboratory, UK.

\begin{tabular}{|c|c|c|c|}
\hline Strain & Other designation & Depositor* & Source \\
\hline Ralstonia basilensis $\mathrm{LMG} 18990^{\mathrm{T}}$ & $\mathrm{RK} 1^{\mathrm{T}}$ & DSMZ & Freshwater sediment (Switzerland) \\
\hline Ralstonia eutropha LMG $1199^{\mathrm{T}}$ & CCUG $1776^{\mathrm{T}}$, ATCC $17697^{\mathrm{T}}$ & ATCC & Soil (USA, 1957) \\
\hline Ralstonia gilardii LMG $5886^{\mathrm{T}}$ & API $141-2-84^{\mathrm{T}}$, CCUG $38401^{\mathrm{T}}$ & D. Monget & Whirlpool \\
\hline Ralstonia paucula $\mathrm{LMG} 3244^{\mathrm{T}}$ & CDC E6793 ${ }^{\mathrm{T}}$, CCUG $12507^{\mathrm{T}}$ & R. Weaver & Human, respiratory tract (USA) \\
\hline Ralstonia pickettii LMG $5942^{\mathrm{T}}$ & CCUG $3318^{\mathrm{T}}$, Pickett K-288 & M. Pickett & Patient after tracheotomy (USA) \\
\hline Ralstonia mannitolytica LMG $6866^{\mathrm{T}}$ & NCIB $10805^{\mathrm{T}}$ & NCIMB & Not known \\
\hline Ralstonia solanacearum LMG $2299^{\mathrm{T}}$ & NCPPB $325^{\mathrm{T}}$, CCUG $14272^{\mathrm{T}}$ & NCPPB & Lycopersicon esculentum (USA) \\
\hline Ralstonia taiwanensis LMG $19424^{\mathrm{T}}$ & $\mathrm{R} 1^{\mathrm{T}}, \mathrm{CCUG} 44338^{\mathrm{T}}$ & & Root nodule of Mimosa pudica (Taiwan) \\
\hline Ralstonia taiwanensis LMG 19425 & G1 & & Root nodule of Mimosa diplotricha (Taiwan) \\
\hline Ralstonia taiwanensis LMG 19426 & Ra5 & & Root nodule of Mimosa pudica (Taiwan) \\
\hline Ralstonia taiwanensis LMG 19427 & $\mathrm{Ra} 7$ & & Root nodule of Mimosa pudica (Taiwan) \\
\hline Ralstonia taiwanensis LMG 19428 & Ra10 & & Root nodule of Mimosa pudica (Taiwan) \\
\hline Ralstonia taiwanensis LMG 19429 & Ra18 & & Root nodule of Mimosa pudica (Taiwan) \\
\hline Ralstonia taiwanensis LMG 19430 & Ga16 & & Root nodule of Mimosa diplotricha (Taiwan) \\
\hline Ralstonia taiwanensis LMG 19431 & Ga18 & & Root nodule of Mimosa diplotricha (Taiwan) \\
\hline Ralstonia taiwanensis LMG 19464 & AUX0106 & J. J. LiPuma & Sputum, cystic fibrosis patient (USA) \\
\hline
\end{tabular}

* Own isolate if not shown.

PAGE, densitometric analysis, and normalization and interpolation of protein profiles were performed as described by Pot et al. (1994); numerical analysis was performed using the GELCOMPAR 4.2 software package (Applied Maths). The profiles were recorded and stored on a PC. The similarity between all pairs of traces was expressed by the Pearson product-moment correlation coefficient, converted for convenience to a percentage value.

DNA preparation. DNA was prepared as described by Pitcher et al. (1989).

Amplified rDNA restriction analysis (ARDRA). Primers fD1 and $\mathrm{rD} 1$ were used for amplification of bacterial 16S rRNA genes by PCR. These primers correspond to nucleotide positions 8-27 and 1524-1540 of the Escherichia coli 16S rRNA gene, respectively, and can be used for amplifying nearly full-length $16 \mathrm{~S}$ rRNA genes (Weisburg et al., 1991). Bacteria were grown on tryptic soy agar (Difco) at $37^{\circ} \mathrm{C}$ for $24 \mathrm{~h}$. Two to three colonies of each strain were harvested and washed twice with sterile distilled water. The cell pellets were dissolved in $100 \mu \mathrm{l}$ sterile distilled water, boiled for $10 \mathrm{~min}$ and centrifuged briefly. A $50 \mu \mathrm{l}$ PCR cocktail containing $10 \mathrm{mM}$ Tris $/ \mathrm{HCl}\left(\mathrm{pH} 8 \cdot 3\right.$ ), $50 \mathrm{mM} \mathrm{KCl}, 2 \mathrm{mM} \mathrm{MgCl}_{2}$, $0.001 \%$ gelatin, $100 \mu \mathrm{M}$ each of dATP, dTTP, dGTP and dCTP, 15 pmol each primer, $2 \cdot 5 \mu$ l supernatant of boiled bacterial cells and 1.0 unit Taq DNA polymerase (PerkinElmer) was subjected to 35 cycles using a GeneAmp PCR system 2400 thermocycler (Perkin-Elmer). The amplification cycles included: 1 cycle of $5 \mathrm{~min}$ at $94{ }^{\circ} \mathrm{C} ; 35$ cycles of $1 \mathrm{~min}$ at $94{ }^{\circ} \mathrm{C}, 1 \mathrm{~min}$ at $60^{\circ} \mathrm{C}$ and $1 \mathrm{~min}$ at $72{ }^{\circ} \mathrm{C}$; and a final extension for $5 \mathrm{~min}$ at $72^{\circ} \mathrm{C}$. The PCR products were checked by electrophoresis in $1.0 \%$ agarose. The remaining PCR products were purified using the High Pure PCR Product Purification kit (Boehringer Mannheim). Purified PCR products $(15 \mu \mathrm{l})$ were digested with $A l u \mathrm{I}, C f_{o} \mathrm{I}, H i n f \mathrm{I}$, MspI and NdeII (Boehringer Mannheim) separately and resolved in $3 \%$ Metaphore agarose (FMC) gels (15 cm long) at $6.7 \mathrm{~V} \mathrm{~cm}^{-1}$ for $4 \mathrm{~h}$. For each strain, the normalized restriction patterns obtained as a combined profile were analysed using the Dice similarity coefficient and the UPGMA clustering algorithm with MVSP 3.1 software (Kovach Computing Services).

Determination of the DNA $\mathbf{G}+\mathbf{C}$ composition. DNA was enzymically degraded into nucleosides as described by Mesbah et al. (1989). The nucleoside mixture was then separated by HPLC using a Waters Symmetry Shield C8 column thermostatted at $37^{\circ} \mathrm{C}$. The solvent was $0.02 \mathrm{M}$ $\mathrm{NH}_{4} \mathrm{H}_{2} \mathrm{PO}_{4}(\mathrm{pH} 4 \cdot 0)$ with $1.5 \%$ acetonitrile. Non-methylated lambda phage DNA (Sigma) was used as the calibration reference.

DNA-DNA hybridizations. DNA-DNA hybridizations were performed with photobiotin-labelled probes in microplate wells as described by Ezaki et al. (1989) using an HTS7000 Bio Assay Reader (Perkin-Elmer) for the fluorescence measurements. The hybridization temperature was $50{ }^{\circ} \mathrm{C}$ and the reaction was carried out in $50 \%$ formamide. Each value was the mean of at least two hybridization experiments.

16S rDNA sequencing. For sequence analysis, purified PCR products of 16S rRNA genes were cloned using the pGEMT Easy Vectors system (Promega). Plasmid DNA was prepared with the Wizard Plus Minipreps DNA Purification kit (Promega). Sequence analysis was performed using an Applied Biosystems 377 DNA Sequencer and the ABI PRISM Dye Terminator Cycle Sequencing Ready Reaction kit. Using the PILEUP program of the Wisconsin Genetics Computer Group package, the sequences were aligned together with reference sequences obtained from GenBank. All the sequences used were almost full length and were derived from the type strain wherever possible. The neighbour-joining method and bootstrap analysis (confidence values estimated from 1000 replications of each sequence) in the CLUSTAL W 1.7 program (Thompson et al., 


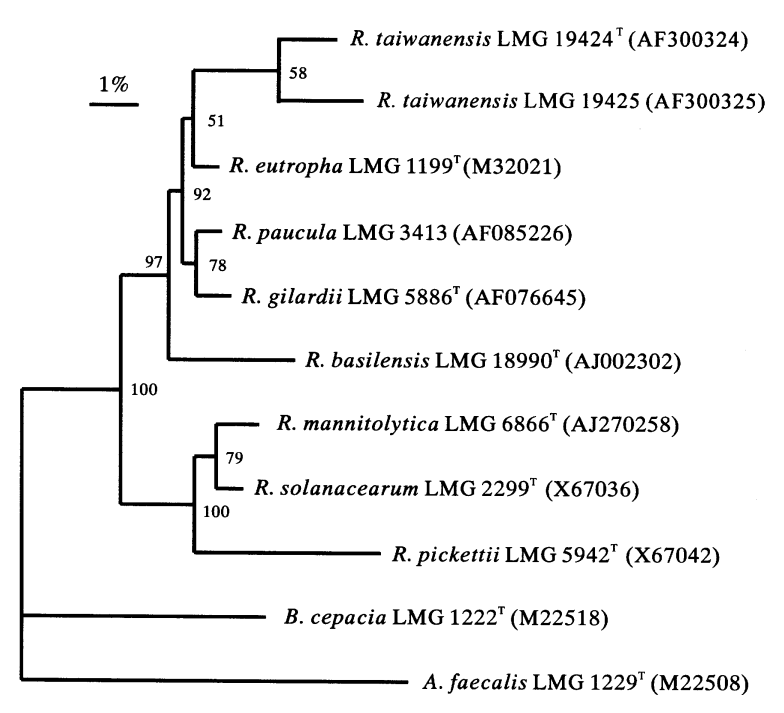

Fig. 1. Neighbour-joining phylogenetic tree of $R$. taiwanensis and related bacteria based on 16S rRNA sequence comparisons. Bootstrap values are indicated at nodes. Scale bar, $1 \%$ sequence dissimilarity (one substitution per $100 \mathrm{nt}$ ). Representative sequences in the dendrogram were obtained from GenBank.

1997) were used to produce a phylogenetic tree. The tree was drawn using the TREEVIEW program (Page, 1996). Sequence identities were calculated using the BIOEDIT program (Hall, 1999).

Biochemical analysis. Classical phenotypic tests were performed as described by De Vos et al. (1985). The API 20NE and API ZYM microtest systems were used according to the recommendations of the manufacturer (bioMérieux). For carbon substrate assimilation tests, BIOLOG GNII microtitre test plates were used. Early exponential phase cultures were used as inocula for the test plates $(150 \mu \mathrm{l}$ per well). Plates were incubated at $28^{\circ} \mathrm{C}$ and examined after 24 and $48 \mathrm{~h}$ to allow for the development of a purple colour indicative of substrate oxidation.
The capacity to grow autotrophically using hydrogen as an energy source was tested as described previously (Schlegel et al., 1961) using Ralstonia sp. strain $\mathrm{CH} 34$ as a positive control. Anaerobic jars (without catalyst) with hydrogenand carbon dioxide-generating envelopes were used to create a hydrogen enriched microaerobic atmosphere.

Antimicrobial susceptibility testing. MIC values towards ampicillin, chloramphenicol, kanamycin, nalidixic acid, penicillin $G$, piperacillin, streptomycin and tetracycline were determined using the agar dilution method conforming to National Committee for Clinical Laboratory Standards (1995) guidelines. Strains were grown on Mueller-Hinton agar (Difco) for $16-20 \mathrm{~h}$ at $28^{\circ} \mathrm{C}$.

\section{RESULTS}

\section{Phylogenetic analysis of 16S rDNA sequences}

The 16S rDNA sequences of isolates LMG $19424^{\mathrm{T}}$ and LMG 19425 were determined. Phylogenetic analysis revealed that both clustered within the $\beta$-Proteobacteria amongst Ralstonia strains. Fig. 1 shows the result of neighbour-joining cluster analysis of strains LMG $19424^{\mathrm{T}}$ and LMG 19425 and related bacteria.

\section{SDS-PAGE of whole-cell proteins}

The whole-cell protein profiles of the eight root nodule isolates were compared with each other and with over 2000 profiles in a database comprising all presently known Burkholderia, Ralstonia and Pandoraea species and many unclassified Gram-negative non-fermenting bacteria (Coenye et al., 1999, 2000; Vandamme et al., 1997, 1999, 2000; P. Vandamme, unpublished data). The root nodule isolates had virtually identical wholecell protein profiles and a high similarity level was found towards strain LMG 19464, an unclassified isolate from the sputum of a cystic fibrosis patient (Fig. 2). No high similarity levels (values above $80 \%$ ) were detected towards reference strains of known species or towards any of the remaining unclassified

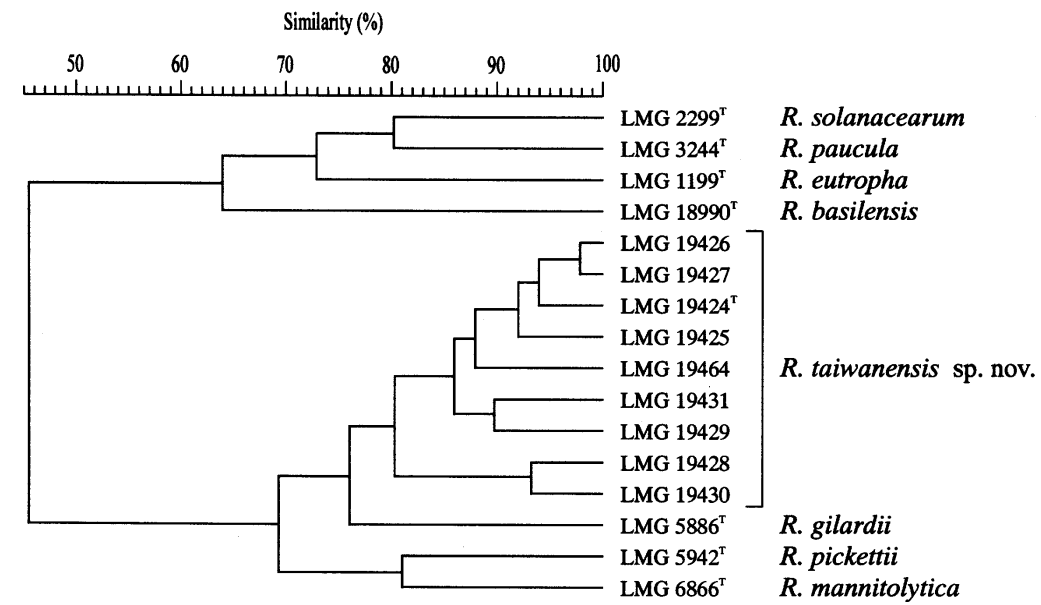

Fig. 2. Dendrogram derived from the unweighted pair group average linkage of correlation coefficients between the wholecell protein patterns of $R$. taiwanensis strains and Ralstonia reference strains studied. The correlation coefficient is expressed as percentage similarity for convenience. 


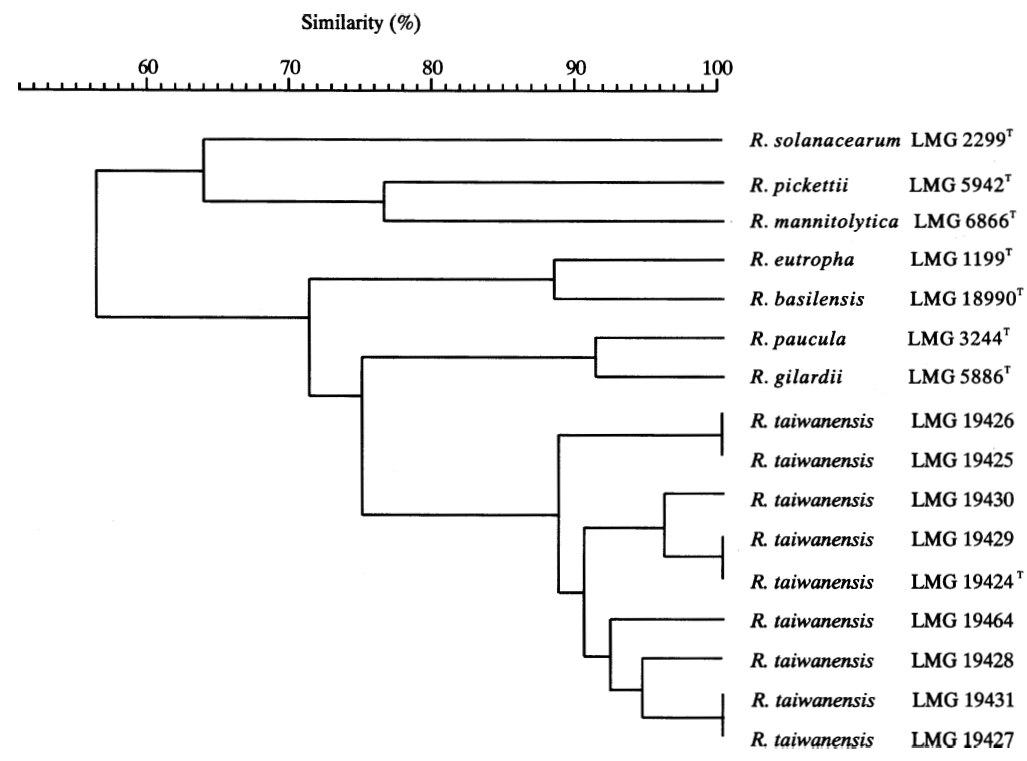

Fig. 3. Dendrogram derived from the unweighted pair group average linkage of Dice similarity coefficients between the combined ARDRA patterns of all strains studied. The correlation coefficient is expressed as percentage similarity for convenience.

Table 2. DNA G $+C$ content and DNA-DNA binding values ( $\%$ ) of strains examined

Strain: 1, R. taiwanensis LMG 19424 $;$ 2, R. taiwanensis LMG 19425; 3, R. taiwanensis LMG 19428; 4, R. taiwanensis LMG

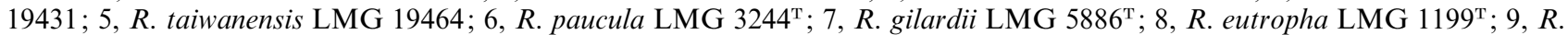
basilensis LMG $18990^{\mathrm{T}}$.

\begin{tabular}{|c|c|c|c|c|c|c|}
\hline \multirow[t]{2}{*}{ Strain } & \multirow[t]{2}{*}{$\mathbf{G}+\mathrm{C}$ content $(\mathrm{mol} \%)$} & \multicolumn{5}{|c|}{ Strain } \\
\hline & & 1 & 2 & 3 & 4 & 5 \\
\hline 1 & $67 \cdot 3$ & 100 & & & & \\
\hline 2 & $66 \cdot 7$ & 71 & 100 & & & \\
\hline 3 & $66 \cdot 7$ & 77 & 70 & 100 & & \\
\hline 4 & $67 \cdot 0$ & 96 & 69 & 80 & 100 & \\
\hline 5 & $67 \cdot 7$ & 65 & & & 71 & 100 \\
\hline 6 & $63 \cdot 7$ & 26 & 25 & & & \\
\hline 7 & $67 \cdot 2$ & 30 & 34 & & & \\
\hline 8 & $66 \cdot 8$ & 46 & 44 & & & \\
\hline 9 & $65 \cdot 4$ & 36 & 31 & & & \\
\hline
\end{tabular}

isolates present in the database. Fig. 2 shows the result of the numerical analysis of the whole-cell protein profiles of the nine isolates and those of Ralstonia reference strains.

\section{ARDRA analysis}

The nine $R$. taiwanensis isolates were examined along with the type strains of the other Ralstonia species. In the numerical analysis of the combined ARDRA patterns (Fig. 3), all $R$. taiwanensis strains examined formed a single cluster. The type strains of all of the reference species occupied distinct positions.

\section{DNA base ratio and DNA-DNA hybridization analysis}

DNA was prepared from strains LMG $19424^{\mathrm{T}}$, LMG 19425, LMG 19428, LMG 19431 and LMG 19464.
Their DNA G+C content was $66 \cdot 7-67 \cdot 7 \mathrm{~mol} \%$ (Table 2). The DNA-DNA binding values among these five strains varied between 65 and $100 \%$ (Table 2). A mean binding value of $45 \%$ was calculated towards $R$. eutropha LMG $1199^{\mathrm{T}}$, their closest phylogenetic neighbour (Fig. 1); values of $36 \%$ and lower were calculated towards the type strains of other Ralstonia species (Table 2).

\section{Antimicrobial susceptibility testing}

The range of MIC values and $\mathrm{MIC}_{50}$ and $\mathrm{MIC}_{90}$ of the strains are given in Table 3.

\section{Biochemical analysis}

Classical biochemical tests, API 20NE tests and API ZYM tests were performed on the nine $R$. taiwanensis 
Table 3. MIC values, $\mathrm{MIC}_{50}$ and $\mathrm{MIC}_{90}$ for the Ralstonia taiwanensis strains investigated

Strains investigated: LMG 19424 ${ }^{\mathrm{T}}$, LMG 19425, LMG 19426, LMG 19427, LMG 19428, LMG 19430 and LMG 19431. The range of MIC values for all antibacterials was

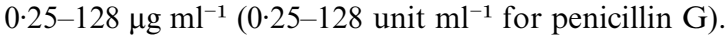

\begin{tabular}{|lcc|}
\hline Antibacterial & $\mathbf{M I C}_{\mathbf{5 0}}\left(\boldsymbol{\mu g} \mathbf{~ m l}^{-\mathbf{1}}\right)$ & $\mathbf{M I C}_{\mathbf{9 0}}\left(\boldsymbol{\mu g} \mathbf{~ m l}^{-\mathbf{1}}\right)$ \\
\hline Ampicillin & 16 & 64 \\
Chloramphenicol & 8 & 16 \\
Kanamycin & 16 & 64 \\
Nalidixic acid & 4 & 16 \\
Penicillin G & 64 & 128 \\
Piperacillin & 8 & 16 \\
Streptomycin & 32 & 128 \\
Tetracycline & $0 \cdot 5$ & 1 \\
\hline
\end{tabular}

isolates. The following characteristics were present in all strains: oxidase and catalase activity; nitrate reduction; aesculin hydrolysis; alkaline phosphatase, C4 esterase, C8 lipase, leucine arylamidase, acid phosphatase and naphthol-AS-BI-phosphohydrolase activity; growth at 30 and $37^{\circ} \mathrm{C}$; growth in 0.5 and
$1.0 \% \mathrm{NaCl}$; and Tween 80 hydrolysis. The following characteristics were absent in all of the $R$. taiwanensis strains: growth on cetrimide agar; growth in the presence of $3 \% \mathrm{NaCl}$; amylase, urease, $\beta$ galactosidase and DNase activity; acid production from D-glucose, D-fructose, adonitol and maltose; production of acid and $\mathrm{H}_{2} \mathrm{~S}$ from triple-sugar iron agar; indole production; arginine dihydrolase, lysine decarboxylase and ornithine decarboxylase activity; and C14 lipase, trypsin, chymotrypsin, $\alpha$ galactosidase, $\beta$-glucuronidase, $\alpha$-glucosidase, $\beta$-glucosidase, $\alpha$-mannosidase, $\alpha$-fucosidase and $N$-acetyl $\beta$ glucosaminidase activity.

The oxidation of carbon substrates, using the BIOLOG GNII microtitre test system, was examined for nine $R$. taiwanensis strains. All strains investigated oxidized Tween 40 , Tween 80 , methyl pyruvate, monomethyl succinate, cis-aconitic acid, formic acid, Dgluconic acid, $\beta$-hydroxybutyric acid, $\alpha$-ketovaleric acid, DL-lactic acid, propionic acid, sebacic acid, succinamic acid, succinic acid, D-alanine, L-alanine, L-alanyl-glycine, L-asparagine, L-aspartic acid, Lornithine, L-glutamic acid, L-leucine, L-proline, Lpyroglutamic acid, L-serine, L-threonine, acetic acid, $\alpha$-hydroxybutyric acid, $\alpha$-ketobutyric acid, itaconic acid, bromosuccinic acid and alaninamide.

\section{Table 4. Differential phenotypic characteristics of $R$. taiwanensis and other Ralstonia species}

Strains: 1, R. basilensis; 2, R. eutropha; 3, R. gilardii; 4, R. paucula; 5, R. pickettii; 6, R. solanacearum; 7, R. taiwanensis. + , Character is present in all strains; - , character is absent in all strains; w, weakly positive reaction; v, strain-dependent result.

\begin{tabular}{|c|c|c|c|c|c|c|c|}
\hline Characteristic & 1 & 2 & 3 & 4 & 5 & 6 & 7 \\
\hline Catalase activity & + & + & + & + & - & + & + \\
\hline Oxidase activity & + & + & - & + & - & + & + \\
\hline Growth in the presence of penicillin $(10 \mu \mathrm{g})$ & - & - & - & - & $\mathrm{W}$ & - & $\mathrm{V}$ \\
\hline Hydrolysis of Tween 80 & + & $\mathrm{w}$ & - & + & + & - & + \\
\hline Growth at $42{ }^{\circ} \mathrm{C}$ & - & + & - & + & + & - & - \\
\hline \multicolumn{8}{|l|}{ Oxidation/fermentation test for: } \\
\hline D-Glucose & - & - & + & - & $\mathrm{W}$ & - & - \\
\hline D-Fructose & - & - & + & - & + & - & - \\
\hline D-Xylose & - & - & + & - & $\mathrm{W}$ & - & - \\
\hline Nitrate reduction & - & + & - & - & + & + & + \\
\hline Urease activity & + & - & - & + & $\mathrm{V}$ & - & - \\
\hline \multicolumn{8}{|l|}{ Assimilation of: } \\
\hline Glucose & - & - & - & - & + & + & - \\
\hline Arabinose & - & - & - & - & + & - & - \\
\hline$N$-Acetylglucosamine & - & + & - & - & + & - & - \\
\hline Caprate & + & + & - & + & $\mathrm{W}$ & - & + \\
\hline Citrate & + & + & - & + & + & + & $\mathrm{V}$ \\
\hline Adipate & + & + & - & + & $\mathrm{W}$ & - & - \\
\hline Phenylacetate & + & + & $\mathrm{W}$ & + & $\mathrm{W}$ & - & + \\
\hline Alkaline phosphatase activity & + & + & + & + & $\mathrm{W}$ & $\mathrm{w}$ & + \\
\hline Acid phosphatase activity & + & + & - & + & $\mathrm{W}$ & $\mathrm{w}$ & + \\
\hline Esterase $\mathrm{C} 4$ activity & + & + & + & + & $\mathrm{W}$ & $\mathrm{W}$ & $\mathrm{W}$ \\
\hline Cystine arylamidase activity & - & - & - & + & - & - & $\mathrm{w}$ \\
\hline Phosphoamidase activity & + & + & $\mathrm{w}$ & + & $\mathrm{W}$ & $\mathrm{w}$ & + \\
\hline Lipase C14 activity & - & - & - & + & + & - & - \\
\hline
\end{tabular}


None of the strains oxidized or assimilated $\alpha$ cyclodextrin, dextrin, glycogen, $N$-acetyl-D-galactosamine, adonitol, cellobiose, i-erythritol, gentiobiose, $\mathrm{m}$-inositol, $\alpha$-D-lactose, lactulose, maltose, D-mannose, D-melibiose, methyl $\beta$-D-glucoside, D-raffinose, Lrhamnose, D-sorbitol, sucrose, D-trehalose, turanose, xylitol, inosine, uridine, thymidine, phenyl ethylamine, putrescine, 2-amino ethanol, 2,3-butanediol, glucose 6-phosphate, glucose 1-phosphate, DL- $\alpha$-glycerol phosphate, hydroxy-L-proline, $N$-acetyl-D-glucosamine, L-arabinose, D-arabitol, D-fructose, L-fucose, D-galactose, $\alpha$-D-glucose, D-mannitol, D-galactonic acid lactone, D-galacturonic acid, glycyl-L-aspartic acid, glycyl-L-glutamic acid, $\gamma$-aminobutyric acid, Dpsicose, D-serine or glucuronamide.

The following carbon substrates were oxidized at variable levels: $\gamma$-hydroxybutyric acid, $\rho$-hydroxy phenylacetic acid, L-histidine, L-phenylalanine, urocanic acid, citric acid, quinic acid, D-saccharic acid, D-glucosaminic acid, $\alpha$-ketoglutaric acid, malonic acid, glycerol, D-glucuronic acid and DL-carnitine. None of the $R$. taiwanensis strains was capable of autotrophic growth.

Table 4 lists differential biochemical characteristics between $R$. taiwanensis and other Ralstonia species.

\section{DISCUSSION}

The present study reports on the polyphasic taxonomic characterization of eight root nodule isolates of $\mathrm{Mim}$ osa species and one human clinical isolate. Analysis of the nearly complete $16 \mathrm{~S}$ rDNA sequences of two root nodule isolates (LMG $19424^{\mathrm{T}}$ and LMG 19425) revealed sequence similarity values of $90 \cdot 7-98 \cdot 8 \%$ towards 16S rDNA sequences of Ralstonia species; the similarity levels towards Burkholderia or Alcaligenes species, the closest relatives of the genus Ralstonia, were below $85 \%$. The DNA G + C content of about 67 mol\% (Table 2) is within the range for the genus Ralstonia, which is between 64 and $69 \mathrm{~mol} \%$ (Vandamme et al., 1999; Coenye et al., 1999; Yabuuchi et al., 1995). DNA-DNA hybridizations among four of the root nodule isolates and the cystic fibrosis isolate revealed high values (Table 2) supporting the value of whole-cell protein electrophoresis as a first line screening method to select for species-level identity. DNA-DNA hybridizations towards the type strains of $R$. eutropha, $R$. gilardii, $R$. paucula and $R$. basilensis, their closest phylogenetic neighbours, revealed low to moderate DNA-DNA binding levels (Table 2) demonstrating unambiguously that this taxon represents a novel Ralstonia species.

These isolates all effectively nodulated both Mimosa species and the presence of nif genes in the genome of $R$. taiwanensis isolates has been demonstrated (W.-M. Chen, L. Moulin, T.-M. Lee, M. Gillis, P. Vandamme and C. Boivin-Masson, unpublished results). Rhizobia are the traditional soil bacteria capable of forming root or stem nodules on various leguminous plants where they undertake symbiotic fixation of atmospheric nitrogen. They are currently divided into six genera with approximately 30 species, including Allorhizobium, Azorhizobium, Bradyrhizobium, Mesorhizobium, Rhizobium and Sinorhizobium (de Lajudie et al., 1998; Nick et al., 1999). Phylogenetically, these bacteria all belong to the $\alpha$-Proteobacteria (Young, 1996). The present report is the first describing isolation and characterization of a $\beta$-proteobacterium capable of root nodule formation and nitrogen fixation in Mimosa species that belong to the Mimosoideae subfamily of the Leguminosae.

Both whole-cell protein and ARDRA analyses indicated that the nine strains described in the present study form a homogeneous group that could easily be differentiated from other Ralstonia species (Figs 2 and $3)$. In addition, classical biochemical tests allowed differentiation of the nine strains from the other Ralstonia species (Table 4). The absence of autotrophic growth and of growth at $42{ }^{\circ} \mathrm{C}$ readily differentiates $R$. taiwanensis from its closest neighbour, $R$. eutropha.

\section{Description of Ralstonia taiwanensis sp. nov.}

Ralstonia taiwanensis (tai.wan.en'sis. N.L. fem. adj. taiwanensis of Taiwan, where the root nodule strains were isolated).

Cells are Gram-negative, non-spore-forming and rodshaped. After $24 \mathrm{~h}$ growth on tryptic soy agar at $30^{\circ} \mathrm{C}$, the mean cell size is about $0.5-0.7 \mu \mathrm{m}$ in width and $0 \cdot 8-2 \cdot 0 \mu \mathrm{m}$ in length. Growth is observed at 28,30 and $37^{\circ} \mathrm{C}$. Catalase- and oxidase-positive. Nitrate is reduced. Aesculin hydrolysed. Tolerant to penicillin $(10 \mu \mathrm{g}$ per disc) and streptomycin $(10 \mu \mathrm{g}$ per disc). No urease, $\beta$-galactosidase or DNase activity. No indole production. No autotrophic growth. Additional characteristics are listed above. The DNA $\mathrm{G}+\mathrm{C}$ content is about $67 \mathrm{~mol} \%$. Isolated from root nodules of Mimosa pudica and Mimosa diplotricha and from sputum of a cystic fibrosis patient and all strains have been deposited in BCCM/LMG Bacteria Collection (Laboratorium voor Microbiologie, Universiteit Gent, Gent, Belgium). The type strain is LMG $19424^{\mathrm{T}}$ (= CCUG $44338^{\mathrm{T}}$ ), which was isolated from the root nodule of Mimosa pudica. Phenotypic characteristics of the type strain are the same as described for the species. Its DNA $\mathrm{G}+\mathrm{C}$ content is $67.3 \mathrm{~mol} \%$.

\section{ACKNOWLEDGEMENTS}

This research was supported in part by grants (NSC 89-2320-B-127-003 and 89-2320-B-127-005) from the National Science Council, Taiwan, ROC. We thank Wei-Ya Zhao and Wen-Juan Xiao for excellent technical assistance.

\section{REFERENCES}

Coenye, T., Falsen, E., Vancanneyt, M., Hoste, B., Govan, J. R. W., Kersters, K. \& Vandamme, P. (1999). Classification of Alcaligenes faecalis-like isolates from the environment and human clinical 
samples as Ralstonia gilardii sp. nov. Int J Syst Bacteriol 49, 405-413.

Coenye, T., Falsen, E., Hoste, B., Ohlén, M., Goris, J., Govan, J. R. W., Gillis, M. \& Vandamme, P. (2000). Description of Pandoraea gen. nov. with Pandoraea apista sp. nov., Pandoraea pulmonicola sp. nov., Pandoraea pnomenusa sp. nov., Pandoraea sputorum sp. nov. and Pandoraea norimbergensis comb. nov. Int J Syst Evol Microbiol 50, 887-899.

De Baere, T., Steyaert, S., Wauters, G., De Vos, P., Goris, J., Coenye, T., Suyama, T., Verschraegen, G. \& Vaneechoutte, M. (2001). Classification of Ralstonia picketii biovar 3/'thomasii' strains (Pickett 1994) and of new isolates related to nosocomial recurrent meningitis as Ralstonia mannitolytica sp. nov. Int $J$ Syst Evol Microbiol 51, 547-558.

De Vos, P., Kersters, K., Falsen, E., Pot, B., Gillis, M., Segers, P. \& De Ley, J (1985). Comamonas Davis and Park 1962 gen. nov., nom. rev. emend., and Comamonas terrigena Hugh 1962 sp. nov., nom. rev. Int J Syst Bacteriol 35, 443-453.

Ezaki, T., Hashimoto, Y. \& Yabuuchi, E. (1989). Fluorometric DNA-DNA hybridization in microdilution wells as an alternative to membrane filter hybridization in which radioisotopes are used to determine genetic relatedness among bacterial strains. Int J Syst Bacteriol 39, 224-229.

Hall, T. A. (1999). BioEdit: a user-friendly biological sequence alignment editor and analysis program for Windows 95/98/NT. Nucleic Acids Symp Ser 41, 95-98.

de Lajudie, P., Laurent-Fulele, E., Willems, A., Torck, U., Coopman, R., Collins, M. D., Kersters, K., Dreyfus, B. \& Gillis, M. (1998). Allorhizobium undicola gen. nov., sp. nov., nitrogen-fixing bacteria that efficiently nodulate Neptunia natans in Senegal. Int J Syst Bacteriol 48, 1277-1290.

Mesbah, M., Premachandran, U. \& Whitman, W. B. (1989). Precise measurement of the $\mathrm{G}+\mathrm{C}$ content of deoxyribonucleic acid by high-performance liquid chromatography. Int $J$ Syst Bacteriol 39, 159-167.

National Committee for Clinical Laboratory Standards (1995). Procedure Volume 15, no. 14. Villanova: NCCLS.

Nick, G., de Lajudie, P., Eardly, B. D., Suomalainen, S., Paulin, L., Zhang, X., Gillis, M. \& Lindström, K. (1999). Sinorhizobium arboris sp. nov. and Sinorhizobium kostiense sp. nov., isolated from leguminous trees in Sudan and Kenya. Int J Syst Bacteriol 49, 1359-1368.

Page, R. D. M. (1996). TREEVIEW: an application to display phylogenetic trees on personal computers. Comput Appl Biosci 12, 357-358.

Palleroni, N. J. \& Doudoroff, M. (1971). Phenotypic characterization and deoxyribonucleic acid homologies of Pseudomonas solanacearum. J Bacteriol 107, 690-696.
Pitcher, D. G, Saunders, N. A. \& Owen, R. J. (1989). Rapid extraction of bacterial genomic DNA with guanidium thiocyanate. Lett Appl Microbiol 8, 109-114.

Pot, B., Vandamme, P. \& Kersters, K. (1994). Analysis of electrophoretic whole-organism protein fingerprints. In Modern Microbial Methods (Chemical Methods in Prokaryotic Systematics Series), pp. 493-521. Edited by M. Goodfellow \& A. G. O'Donnell. Chichester: Wiley.

Riley, P. S. \& Weaver, R. E. (1975). Recognition of Pseudomonas pickettii in the clinical laboratory: biochemical characterization of 62 strains. J Clin Microbiol 1, 61-64.

Schlegel, H. G, Kaltwasser, H. \& Gottschalk, G. (1961). Ein Sumbersverfahren zur Kultur wasserstoffoxidierender Bakterien: Wachstum physiologische Untersuchungen. Arch Mikrobiol 38, 209-222.

Steinle, P., Stucki, G., Stettler, R. \& Hanselmann, K. W. (1998). Aerobic mineralization of 2,6-dichlorophenol by Ralstonia sp. strain RK1. Appl Environ Microbiol 64, 2566-2571.

Thompson, J. D, Gibson, T. J, Plewniak, F., Jeanmougin, F. \& Higgins, D. G. (1997). The CLUSTAL $x$ windows interface: flexible strategies for multiple sequence alignment aided by quality analysis tools. Nucleic Acids Res 24, 4876-4882.

Vandamme P., Holmes, B., Vancanneyt, M. \& 8 other authors (1997). Occurrence of multiple genomovars of Burkholderia cepacia in cystic fibrosis patients and proposal of Burkholderia multivorans sp. nov. Int J Syst Bacteriol 47, 1188-1200.

Vandamme, P., Goris, J., Coenye, T., Hoste, B., Janssens, D., Kersters, K., De Vos, P. \& Falsen, E. (1999). Assignment of Centers for Disease Control group IVc-2 to the genus Ralstonia as Ralstonia paucula sp. nov. Int J Syst Bacteriol 49, 663-669.

Vandamme, P., Mahenthiralingam, E., Holmes, B., Coenye, T., Hoste, B., De Vos, P., Henry, D. \& Speert, D. P. (2000). Identification and population structure of Burkholderia stabilis sp. nov. (formerly Burkholderia cepacia genomovar IV). J Clin Microbiol 38, 1042-1047.

Vincent, J. M. (1970). A Manual for the Practical Study of Rootnodule Bacteria. IBP Handbook 15. Oxford: Blackwell.

Weisburg, W. G., Barns, S. M., Pelletier, D. A. \& Lane, D. J. (1991). $16 \mathrm{~S}$ ribosomal DNA amplification for phylogenetic study. $J$ Bacteriol 173, 697-703.

Yabuuchi, E., Kosako, Y., Yano, I., Hotta, H. \& Nishiuchi, Y. (1995). Transfer of two Burkholderia and an Alcaligenes species to Ralstonia gen. nov.: proposal of Ralstonia pickettii (Ralston, Palleroni and Doudoroff 1973) comb. nov., Ralstonia solanacearum (Smith 1896) comb. nov. and Ralstonia eutropha (Davis 1969) comb. nov. Microbiol Immunol 39, 897-904.

Young, J. P. W. (1996). Phylogeny and taxonomy of rhizobia. Plant Soil 186, 45-52. 